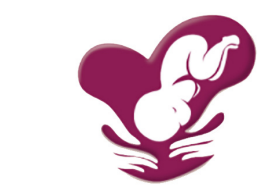

Published By : PERINASIA The Indonesian Society of Perinatology

\title{
Early detection of Fetal Acrania on first-trimester sonography: a case report
}

\author{
I Nyoman Hariyasa Sanjaya ${ }^{1 *}$, Cokorda Istri Mirayani Pemayun², Ni Komang Anik \\ Pirgantari ${ }^{3}$, Made Diah Vendita Sakuntari ${ }^{3}$, Ni Wayan Dewi Purwanti ${ }^{3}$, \\ NI Putu Nining Gianni ${ }^{3}$, Ni Luh Made Diah Mas Cahyani Putri ${ }^{3}$, \\ Ni Luh Md Dwi Laxmi Satriani ${ }^{3}$, Firsta Sesarina Mintariani ${ }^{3}$, \\ Ni Luh Putu Yulia Padmawati ${ }^{3}$, Anak Agung Wahyu Putri Agustini ${ }^{3}$
}

\begin{abstract}
'Obstetric and Gynecologic Department Medical Faculty Udayana University Sanglah General Hospital, Denpasar, Bali, Indonesia.

${ }^{2}$ Outpatient Clinic Sanglah General Hospital, Denpasar, Bali, Indonesia. ${ }^{3}$ Kasih Medika Pregnancy School, Denpasar, Bali, Indonesia.
\end{abstract}

*Corresponding to:

I Nyoman Hariyasa Sanjaya. Obstetric and Gynecologic Department, Faculty of Medicine, Universitas Udayana/Sanglah General Hospital.

hariyasa_sanjaya@unud.ac.id

Received: 2020-10-15 Accepted: 2021-01-22 Published: 2021-02-26

\section{ABSTRACT}

Introduction: Fetal Acrania is a rare fetal malformation characterized by the complete or partial absence of a skull covering the fetal brain. In the absence of a hard covering of the soft brain tissue, Acrania is known as a universally lethal malformation. Here we present a Fetal Acrania case detected by sonographic examination at our Center.

Case Description: A 36 years old female was referred to the obstetric department to undergo an in-depth sonographic evaluation as a previous examination reveals a potential congenital fetal anomaly. Our sonographic evaluation revealed a singleton, live fetus, 12 weeks gestational age in cephalic presentation and longitudinal lie. One obvious malformation was a well-formed fetal brain without the surrounding cranium (Acrania). The absence of cranium was the main and only malformation. The absence of cranium was evident as the fetal brain was easily compressed on probe pressure, and the brain appeared like floating in the amniotic fluid over the base of the skull. Therapeutic abortion was carried out. The termination was conducted by administering four tablets of $200 \mathrm{mcg}$ misoprostol sublingually and repeated 24 hours later. No adverse reaction or complication on termination. The aborted fetal examination confirmed the lack of fetal cranium.

Conclusion: Although seemingly obvious, the first-trimester diagnosis of fetal Acrania must be made with caution as the fetal cranium is not fully calcified before $10-11$ weeks. As Acrania is a universally lethal malformation, therapeutic abortion is indicated.

Keywords: Acrania, abortion, brain, cranium.

Cite This Article: Sanjaya, I.N.H., Pemayun, C.I.M., Pirgantari, N.K.A., Sakuntari, M.D.V., Purwanti, N.W.D., Gianni, N.P.N., Putri, N.L.M.D.M.C., Satriani, N.L.M.D.L., Mintariani, F.S., Padmawati, N.L.P.Y., Agustini, A.A.W.P. 2021. Early detection of Fetal Acrania on first-trimester sonography: a case report. Indonesian Society Of Perinatology 2(1): 6-8. D0I: 10.51559/inajperinatol. v112.8

\section{INTRODUCTION}

Fetal Acrania is a very rare fetal malformation characterized by the complete or partial absence of a skull brain covering the fetal brain. Failure of mesenchymal migration during the early stage of embryogenesis (around the $4^{\text {th }}$ week) is proposed as the primary mechanism. ${ }^{1,2}$ The absence of hard covering of the soft brain tissue, Acrania is known as universally lethal malformation. ${ }^{2}$ Here, we present a Fetal Acrania case detected by sonographic examination at our Center.

\section{CASE}

A 36 years old female was referred to the obstetric department to undergo an in-depth sonographic evaluation as a previous examination reveals a potential congenital fetal anomaly. Our sonographic evaluation revealed a singleton, live fetus, 12 weeks gestational age in cephalic presentation and longitudinal lie. One obvious malformation was a well-formed fetal brain without the surrounding cranium (Acrania) (Figure 1,2).

The absence of cranium was the main and only malformation. The convolutions, inter-hemispheric fissure and sulci of the brain can be identified. Also, a thin membranous structure was the only structure covering the brain. The facial structures were seeming non-malformed. The absence of cranium was evident as the brain tissue compressible on probe pressure, and the brain appeared like floating in the amniotic fluid protruding from the skull base. Other than a slight increase in the amount of amniotic fluid, no other fetal anomaly was seen. The cardiac rate (168 beats / min) and rhythm were normal.

After informed about the finding, the patient was counseled regarding the fetal condition, gestational prognosis. As it is a universally lethal malformation, we recommended a pregnancy termination. The patient agreed, and a therapeutic abortion was conducted by administering four tablets of $200 \mathrm{mcg}$ misoprostol sublingually and repeated 24 hours later. No adverse reaction or complication during the procedure. The aborted fetal examination confirmed the lack of fetal cranium. 


\section{DISCUSSION}

Although seemingly obvious, some notes have to be remembered about fetal cranium malformation. First, the first-trimester diagnosis of fetal Acrania must be made with caution as the fetal cranium is not fully calcified before 10-
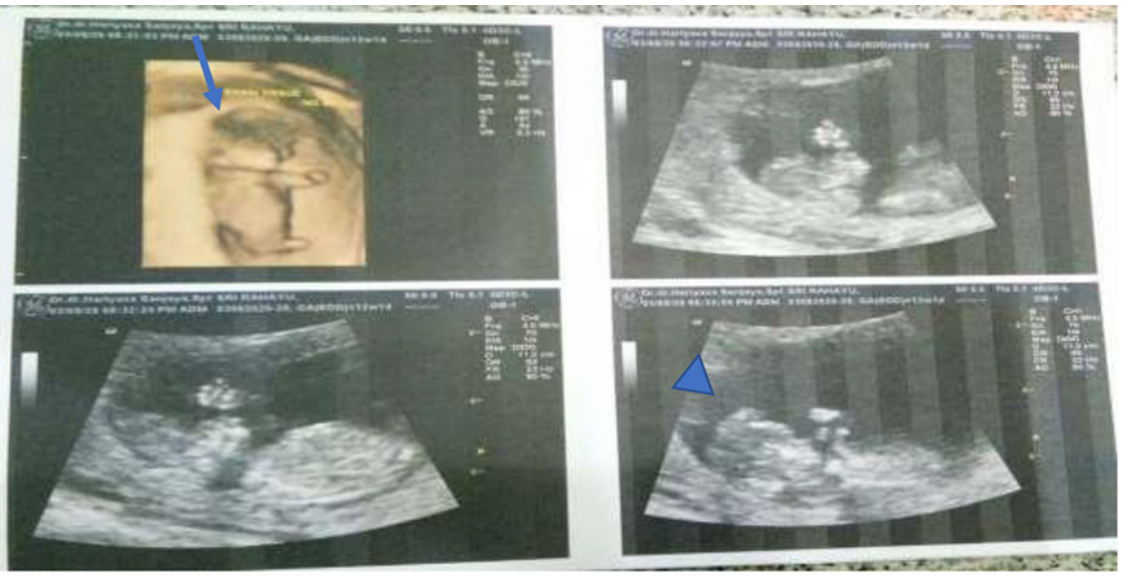

Figure 1. Ultrasound of the fetal brain during 12 weeks of gestational age using the 3.5 $\mathrm{MHz}$ probe in the axial plane. No cranial bone is seen encapsulating the brain (arrows), and the brain is directly exposed to the amniotic fluid (arrowhead). perfect midsagittal image. The frequent pitfalls are when the sonograph has only taken the midsagittal views of the fetus, and misdiagnosis may occur. The absence of cranial ossification may be missed as it appears relatively normal. Here the emphasis to specifically look for frontal bone ossification in the axial and coronal planes is imperative., ${ }^{2,45}$ A novel US technology, such as 3-D ultrasonography, may improve fetal visualization, thus significantly aid the detection of fetal Acrania. ${ }^{2,6}$ Second point to notes is the possibility of severe Osteogenesis imperfecta or other congenital hypophosphatasia that may result in low mineralization of the calvarium. Sonography may reveal a poorly defined calvaria, a thin and possibly malformed, particularly difficult to differentiate from Acrania. It is also important to screen for any family history fetal malformation, as Osteogenesis imperfecta frequently appears with the knowledge of family relatives with fracture during early childhood or delivery.,

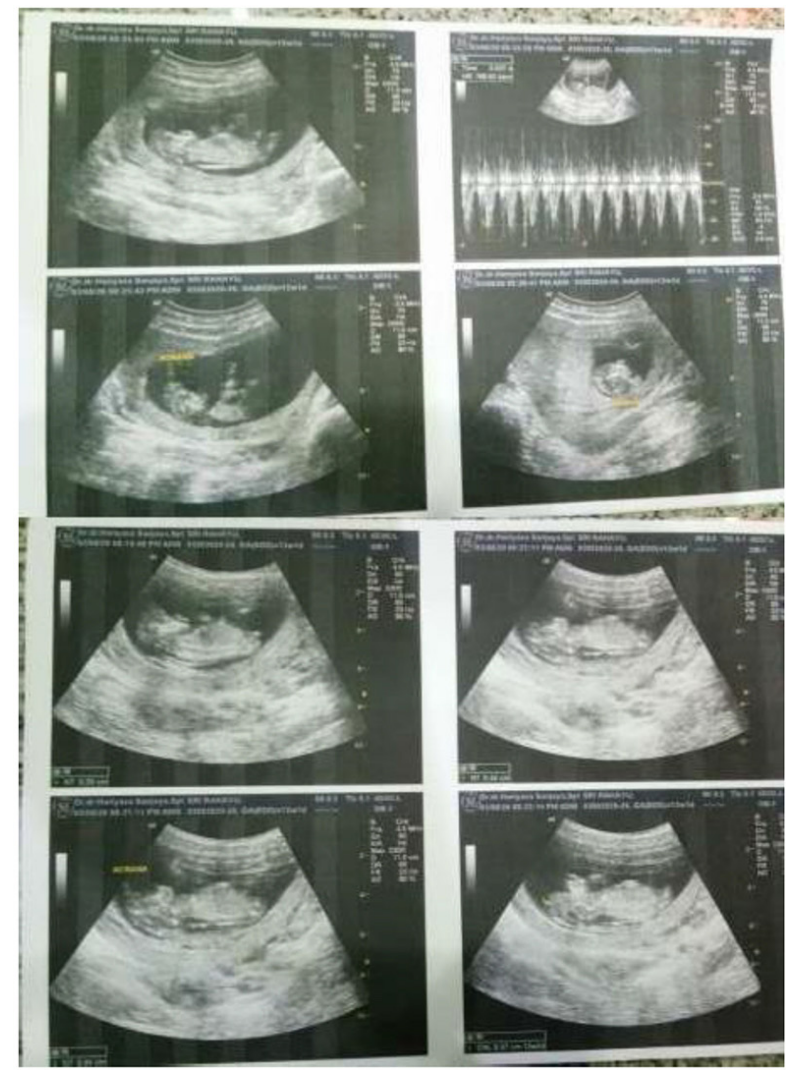

Figure 2. Ultrasound of the fetal brain during 12 weeks of gestational age using the $3.5 \mathrm{MHz}$ probe in the coronal plane. No cranial bone is seen encapsulating the brain.

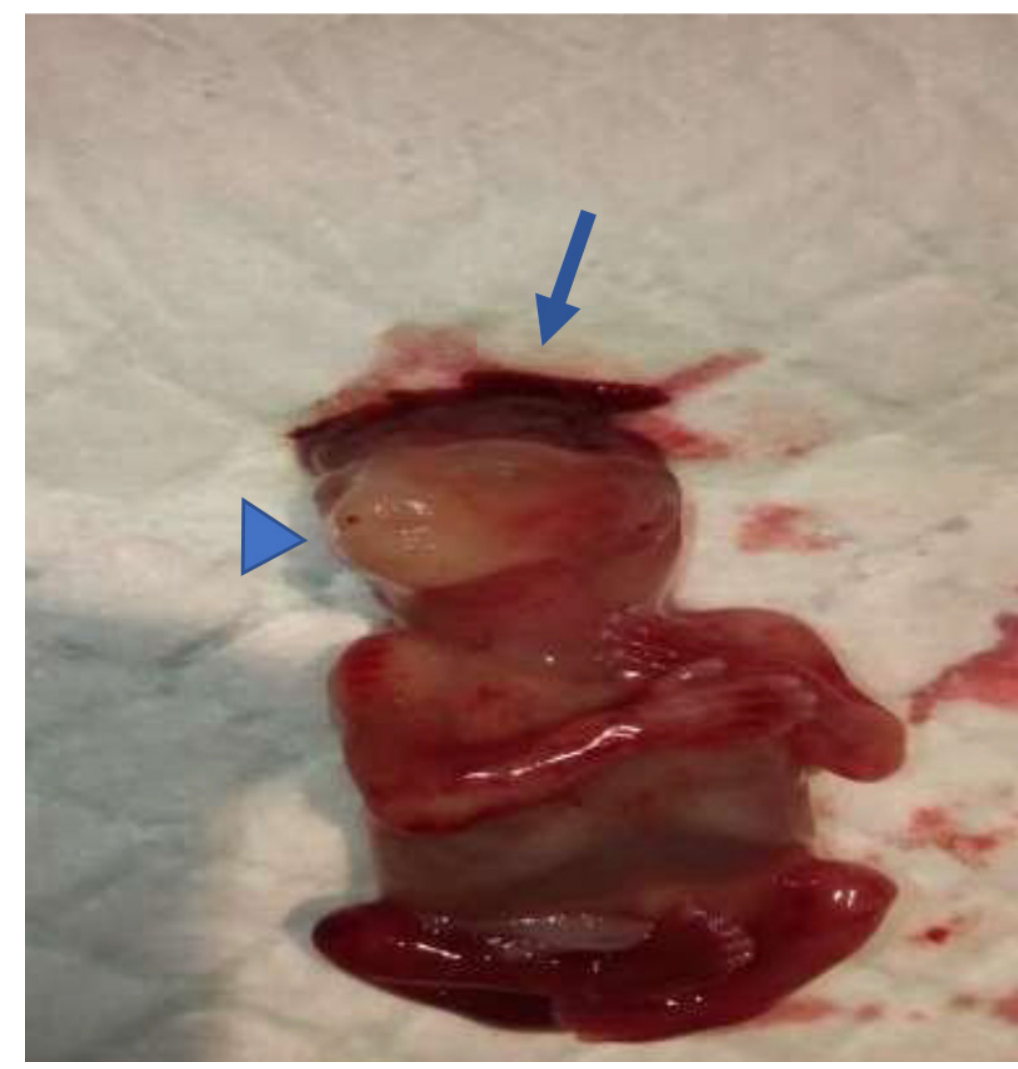

Figure 3. Aborted fetus at gestational age 12 weeks. An aborted fetus revealed a brain without cranium covering and protruding above the skull base. Arrows $=$ fetal brain, Arrowhead $=$ fetal face 


\section{CONCLUSION}

Fetal Acrania is a very rare fetal malformation characterized by the complete or partial absence of a skull brain covering the fetal brain. Although seemingly obvious, the first-trimester diagnosis of fetal Acrania must be made with caution as the fetal cranium is not fully calcified before 10-11 weeks. As Acrania is a universally lethal malformation, therapeutic abortion is indicated.

\section{PATIENT CONSENT}

Patients have agreed and given their consent for her case reported in the academic journal without revealing any personal identity.

\section{CONFLICT OF INTEREST}

All authors declare that there is no conflict of interest.

\section{AUTHOR CONTRIBUTION}

All authors have contributed equally during all phases of the study, including, conducting the study, drafting and revising the manuscript, giving final approval, and agreeing to be accountable.

\section{FUNDING}

All authors have no external support or additional funding to report.

\section{REFERENCES}

1. Kaya H, Sezik M, Özkaya O, Aydın AR. Miadında fetal akrania. Perinatoloji Derg. 2004;12(2):96-9.

2. Amin MU, Mahmood R, Nafees M, Shakoor T. Fetal acrania - prenatal sonographic diagnosis and imaging features of aborted fetal brain. $J$ Radiol Case Rep. 2009;3(7):27-34. Available from: https://europepmc.org/articles/ PMC3303320

3. Cincore V, Ninios AP, Pavlik J, Hsu C-D. Prenatal Diagnosis of Acrania Associated With Amniotic Band Syndrome. Obstet Gynecol.
2003;102(Supplement):1176-8. Available from: http://dx.doi.org/10.1097/00006250200311001-00020

4. Fong KW, Toi A, Salem S, Hornberger LK, Chitayat D, Keating SJ, et al. Detection of Fetal Structural Abnormalities with US during Early Pregnancy. RadioGraphics. 2004;24(1):157-74. Available from: http://dx.doi.org/10.1148/ rg. 241035027

5. Johnson SP, Sebire NJ, Snijders RJM, Tunkel $\mathrm{S}$, Nicolaides KH. Ultrasound screening for anencephaly at 10-14 weeks of gestation. Ultrasound Obstet Gynecol. 1997;9(1):14-6. Available from: http://dx.doi.org/10.1046/ j.1469-0705.1997.09010014.x

6. Liu I-F, Chang C-H, Yu C-H, Cheng Y-C, Chang F-M. Prenatal diagnosis of fetal Acrania using three-dimensional ultrasound. Ultrasound Med Biol. 2005;31(2):175-8. Available from: http:// dx.doi.org/10.1016/j.ultrasmedbio.2004.10.005

7. Mannes EJ, Crelin ES, Hobbins JS, Viscomi GN, Alcebo L. Sonographic demonstration of fetal acrania. Am J Roentgenol. 1982;139(1):181-2. Available from: http://dx.doi.org/10.2214/ ajr.139.1.181

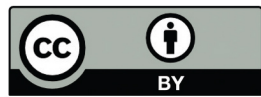

This work is licensed under a Creative Commons Attribution 